\title{
Enfoque de aprendizaje basado en tareas en el desarrollo de la habilidad del habla
}

\section{Task-based learning approach in the development of the speaking skill}

Marco Antonio Bravo Montenegro. ${ }^{1}$, Byron Rafael Soria Guerrero. ${ }^{2} \&$ David Antonio Ureña Lara. ${ }^{3}$

Recibido: 02-12-2019 / Revisado: 26-12-2019 / Aceptado: 06-01-2020 / Publicado: 07-02-2020

\begin{abstract}
DOI: https://doi.org/10.33262/concienciadigital.v3i1.1.1139
\end{abstract}

The central purpose of the present scientific article was to determine the influence of the Taskbased Learning Approach helps to strengthen the speaking students' ability from the Languages Center of the Universidad Nacional de Chimborazo level 1. To determine the effectiveness of this procedure, a pre-test and post-test based on the Cambridge KET exam - speaking part, were given to the students of First level at the Language Center of the Universidad Nacional de Chimborazo, classes 1K4 and 1E4 during the period Octo-ber 2018 - March 2019. A manual for the teacher was designed which was used during the procedure in the classroom. The interpretation of data was done before and after the work in the classroom. The design of the manual for the teacher was made based on the three stages of the process of a task: pre-task, task itself and post-task with the use of various types of tasks such as individual, group, open, closed, and information gap tasks, taking into consideration the challenge and incentive that each task implies in the increase of learners' speaking skill. After the procedure has ended with the implementation of the proposal, the data analysis obtained from the pre-test and post-test were analyzed through the use of the T-student test. The conclusion shows that effectively the Task-based Learn-ing Approach had a positive influence on the development of the students' oral production who improved their ability to speak. Therefore, it is recommended that teachers apply this proposal with the Task-based Learning Approach to enhance the oral performance of students.

Keywords: Speaking - motivation - challenge - treatment - pre-task

\footnotetext{
${ }^{1}$ Escuela Superior Politécnica de Chimborazo, Facultad de Salud Pública. Riobamba, Ecuador, marcoa.bravo@espoch.edu.ec

${ }^{2}$ Escuela Superior Politécnica de Chimborazo, Facultad de Administración de Empresas, Riobamba, Ecuador. byron.soria@espoch.edu.ec

${ }^{3}$ Escuela Superior Politécnica de Chimborazo, Facultad de Salud Pública. Riobamba, Ecuador. david.urenia@espoch.edu.ec
} 


\section{Resumen}

El propósito central del presente artículo científico fue determinar la influencia del Enfoque de aprendizaje basado en tareas que ayuda a fortalecer la capacidad de los estudiantes de habla del Centro de Idiomas de la Universidad Nacional de Chimborazo nivel 1. Para determinar la efectividad de este procedimiento, un Los exámenes previos y posteriores basados en el examen Cambridge KET - parte oral, se dieron a los estudiantes de primer nivel en el Centro de Idiomas de la Universidad Nacional de Chimborazo, clases 1K4 y 1E4 durante el período de octubre de 2018 a marzo de 2019. A Se diseñó un manual para el maestro que se utilizó durante el procedimiento en el aula. La interpretación de los datos se realizó antes y después del trabajo en el aula. El diseño del manual para el maestro se realizó en base a las tres etapas del proceso de una tarea: tarea previa, tarea propia y tarea posterior con el uso de varios tipos de tareas como individual, grupal, abierta, cerrada, y tareas de falta de información, teniendo en cuenta el desafío y el incentivo que cada tarea implica en el aumento de la habilidad de hablar de los alumnos. Una vez que el procedimiento ha finalizado con la implementación de la propuesta, el análisis de datos obtenido de la prueba previa y posterior se analizó mediante el uso de la prueba T-student. La conclusión muestra que, efectivamente, el Enfoque de aprendizaje basado en tareas tuvo una influencia positiva en el desarrollo de la producción oral de los estudiantes que mejoraron su capacidad de hablar. Por lo tanto, se recomienda que los maestros apliquen esta propuesta con el enfoque de aprendizaje basado en tareas para mejorar el rendimiento oral de los estudiantes.

Palabras claves: Hablar - motivación - reto - tratamiento - pre-tarea - tarea

\section{Introduction}

Language is used by members of a social group or culture in spoken, manual, or written ways to express ideas, thoughts, and feelings for communication purposes Language as part of any culture is transmitted from generation to generation to convey meaning. That is the reason why teaching languages are emphasized in this globalized era. In the present, English is the language for global communication, science, business, fashion, and technology, among other fields. It has become a "lingua franca" among language users that do not come from the same culture (Crystal, 2003). Being a global language, English is needed to learn by people from Ecuador; therefore, it is demanding to create proposals that help in the teaching and learning process. Students must acquire the B2 level at the end of the university studies, and they need instructors' support and commitment to accomplish this goal.

In this context, a proposal focused on a Task-based Learning Approach was developed to help in the improvement of speaking skills. It was designed, taking into consideration the process of task with pre-task activities, task activities, and post-tasks activities with the ultimate goal of the challenge, motivate, and scaffold students in the construction of fluency, accuracy, and good pronunciation of the target language.

In Ecuador, the English proficiency has been catalogued as low a deficient. Most of the people and institutions in Ecuador are well aware of this situation. Moreover, they have already identified 
several problems in the productive skills usage such as speaking and writing rather that the input skills. Ecuadorian people identified as the main problem the poor use of the speaking skill in their daily life. Also, they mention that speaking skill is much harder to master than the other skills (British Council, 2015). Ecuadorian students state their emphasis in the oral production difficulty because they fear to commit mistakes using the grammar and the pronunciation of the words which are unknown for them. Therefore, it is a need to improve speaking skills through pronunciation drills (Gonzales, et al., 2015). Furthermore, it can be stated that there is a poor quality in English education due to poor teaching skills which do not allow achieving education objectives (Quezada, Benítez, Vargas, \& Zúñiga, 2017); thus, new methodologies, approaches and techniques are a must such as Task-based learning for improving Ecuadorian students' English proficiency.

Even though new methodologies of English teaching had been proposed through the time teachers continue applying old-fashioned methodology. Teacher centered approach rather than modern (Belias, Sdrolias, Kakkos, Koutiva, \& Koustelios, 2013) ones such as CLIL or communicative approaches is the current method in classes at UNACH. For this cause, there is a poor speaking production. Students listen to the teacher and he or she disserts something especially about grammar patterns without any interaction moments or tasks. Therefore, the transmission of knowledge has been developed with useless lectures. An-other issue of the problematic in speaking production is the negative personality factors such as anxiety, stress and shyness which end in low level of speaking interaction (Haidara, 2016). Although, students have studied English for a long period of time their speaking performance is consider as a weakness. Students have management of grammar and vocabulary but they do not produce complete phrases orally. They evidence fear of mistakes, stress, shyness, indecision, and low rates of self-confidence. Learners do not interact among them and they do not produce English language independently because they also have fearful criticism (Leong \& Ahmadi, 2016).

Besides, students are not enough motivated and there is a lack of students agency as major consequence (Leong \& Ahmadi, 2016). Motivation can be very influential for it integrates people who learn (Merisuo-Storm, 2007 as cited in Leong and Ahmadi, 2016). Students who are motivated are sensitive to produce a good pronunciation and they improve their speaking performance. Hence, if teachers do not build a motivational class-room environment and language learning process, students will not evidence any important improvement in English language learning. Moreover, a positive attitude might improve students' speaking performance.

Besides, Inappropriate address of linguistics components of language causes that students lack of those important components of the language. Learners are not aware about phonology, syntax, semantics, and vocabulary because teachers do not address them in English speaking skills activities. Phonology is the branch of linguistics that studies the sounds systems of the language (Crystal, 2008); therefore, it deals with pronunciation issues. It is well-known that pronunciation and spelling of English words are different hence it can cause many problems at the time of speaking practice (Leong \& Ahmadi, 2016). 
Specifically, at Universidad Nacional de Chimborazo, there is a low level of speaking production and performance of the most of the students. Mean they were exposed to di-agnostic, the researcher had found that students do not communicate their ideas in an oral way. Most of them show low of speaking performance.

To summarize, there are very low production of speaking in Latin America, Ecuador, and at UNACH. Therefore, it is necessary and essential to implement other teaching approaches to solve this important issue. Because, speaking as an important skill of English language; needs to be enhanced by learners in order to have an effective language learning and communication. For this reason, the study is focused in the appropriate use of Task-based learning approach in the development of speaking skills of students at Universidad Nacional de Chimborazo. This problem has its causes and their effects.

\section{Methodology}

The present study was developed to research about the proper implementation of activities based on tasks focused in speaking ability. Based on the category of quasi experimental research; thus, it permits the adequate use of several devices and statistic techniques, such as tabular displays and graphs, to manage and display qualitative data. Comparative research was used to mean common sequences and confine treads from the context laden environment (Ellis, 2003). The research applied for this type of analysis intended to compare two different groups to investigate and understand the impact of using task-based activities.

Moreover, quasi-experimental research was the used method because it is a qualitative methodology extensively used in social science. Thus, precise and meticulous analysis techniques that steadily develop objective and reliable findings need to be determined (Miles \&Huberman $1984,1994)$. In consequence, quasi-experimental study proceeds of research of a person or group, especially of a social phenomenon.

Based on Samuda (2001), qualitative research through comparative strategies is a methodological soft option than quantitative analysis. In the current study, qualitative re-search had five major methods for collecting data: observation, interviewing, ethno-graphic fieldwork, discourse analysis, and textual analysis. Meanwhile, Zacharias (2012) defines that qualitative research wants to provide a detailed description of the learners involved in the study, and it is used in order to comprehend what happened in one particular classroom or what the experiences of specific language learners and teachers were.

The study was performed to investigate how efficient the use of task-based activities for enhancing the speaking skill. That is why it is based on qualitative data, which was the most appropriate method to research (Bernal, 2010). Qualitative techniques were occupied with collecting, analyzing 
data, and comparing the expected results.

This research developed a quasi-experimental type of research because a pre-test, a post-test have been applied to obtain data.

The students from the language Center at Universidad Nacional de Chimborazo were participants of this research. They were in level 1, with ages around 18-22, all of them Ecuadorian citizens. This study had a duration of one term 2 hours weekly from October 2018 - February 2019 and was divided into two groups who were chosen meticulously. The control and the experimental groups were formed by 60 students who were administered as the table below shows.

Table 1. Population

\begin{tabular}{lll}
\hline Groups of Students & Number of students & \% \\
\hline Control & 30 & $50 \%$ \\
Experimental & 30 & $50 \%$ \\
\hline
\end{tabular}

Author: Soria, B. (2018)

The focus groups were carried out by 60 participants of two classes from the level 1 at Universidad Nacional de Chimborazo. Moreover, the instruments in this study are pre- test and post- test that have been directed to both control and experimental groups of students. This type of data collection is a valuable tool which can help to answer questions (Vromen, 2010), this research tool is to determine how task-based learning could be used to enhance learners speaking skill and their learning of English.

Table 2. Data collection plan

\begin{tabular}{ll}
\hline Purpose: & To achieve the aims for the present study \\
\hline Place: & Language Center at Universidad Nacional de Chimborazo \\
Target group: & Students of first level. Classes 1K4 and 1E4 \\
Theme: & Task-based learning approach in the development in the speaking skill \\
Researcher: & Soria Byron \\
Time for the collection of infor- & September 2018- February 2019 \\
mation: & \\
Techniques: & Testing and classroom intervention \\
Instruments: & KET Exam Speaking part \\
& Kinds of tasks \\
\hline
\end{tabular}

Author: Soria, B. (2018) 


\section{Method of data collection and analysis}

For collecting quantitative data, any random sampling technique was implemented, in-stead two groups of similar level and language proficiency have been chosen intention-ally, and in such a way, that each group had a chance of being selected (Peña \& Onatra, 2009). A pre-test and a posttest have been implemented with group A, Control Group, as well as with Group B, Experimental Group. The test has been assessed focusing on students' speaking skills proficiency the beginning and at the end of the intervention process. The instrument was a validated test from Cambridge which part is focused on speaking skills. This test was Key English Test, Speaking part.

As the current study was focused on the application of task-based learning in order to enhance speaking skills, it was necessary to develop classroom observations. Classroom observations were carried about during the whole process of speaking. Therefore, the teacher was monitoring the pretask activities, task activities, and post task activities. Furthermore, the researcher used a checklist in order to keep a record of the students' behavior and advancement.

The questionnaires which were implemented in the current research were focused on the pre and post-tests. Furthermore, during the application of the proposal, the students took different questionnaires as guides for their oral presentations.

The pre-test was taken by the students to obtain data referring to the students' level before the teacher's intervention through the KET exam. It consisted on 22 questions about familiar topics for the students that had to answer individually. The second question consisted in reading a small picture which contains information about a book store and asks and answer questions with the teacher.

After the implementation of the proposal, the researcher applied the Post-test which be-longs to the KET exam with similar characteristics to the Pre-test.

A rubric which was retrieved from Cambridge home page (2018) was used along the whole process of the proposal implementation. This rubric contained three major criteria namely the use of grammar and vocabulary, pronunciation, and interactive communication. The first criterion assesses how efficiently the language learner shows a good level of control in simple grammatical forms as well as the appropriate use of vocabulary during students' utterances related to everyday situations. The second criterion was pronunciation. It deals with the intelligible control of phonological features in production of sounds and word levels. And the third criterion was interactive communication. It assessed the students' ability to maintain simple conversations that require little prompting and support. That rubric also had 5 bands from 0 which is the lowest to 5 which is the highest level of speaking performance.

For the accomplishment of the goals, this research used descriptive and inferential statistics. Williams (2018) conceptualizes to descriptive statistics as the tool to summarize data. The current 
research aimed to measure the students' speaking performance before and after the treatment in the classroom. 60 students were assessed through three criteria on a scale from 0 to 15 . The ratings were collected and analyzed in order to produce the correspondent summary of the findings. It was developed through Spss statistical software to measure the central tendency (mean, media, and moda), variability and dispersion.

Bundly (2018) says that inferential statistics provide effective data for description and prediction. It is the branch of statistics that deals with the generation of insights from statistical data. With this kind of statistics, the researcher proved the alternative hypothesis and rejected the null hypothesis. It was also helpful to draw conclusions from the data which was obtained from the intended population tests.

\section{Results}

The data of this study were collected from 60 students of Language Center at Universidad Nacional de Chimborazo. The objective of this research was to determine the impact of Task-Based Approach to enhance English speaking skill in the Language Center at Universidad Nacional de Chimborazo. The data were gathered by two different means, which are Pre and post-test. Finally, descriptive and inferential statistic methods were used for analyzing and presenting the results.

Based upon the information presented before, two groups of students took part of this study, the control group and the experimental one. The first group had a population of 30 learners and the second group was formed by 30 students. Besides, two tests were taken for the students before (pre-test) and after (post-test) the teachers' treatment in the classroom setting to both the control and the experimental groups. Thereupon, the data obtained were presented and detailed below: With 60 valid cases which belong to the control and experimental group of this study, the mean, median, and mode have been calculated. First, the mean or average was calculated by making the sum of the general results and dividing it with the total number of the population in each group of study. Therefore, the mean in the pre-test of the control group was 4,93 and the mean in the posttest was 6,60; on the other hand, the mean of the experimental group in the pre-test was 5, 30 while in the post-test the result is 10,83 . It is clearly stated the big difference in the results of the experimental group where the researcher implemented the proposal.

The median is the middle value in the general table of results. The median was calculated by first listing the obtained data in numerical order. After that, the value in the middle of that list was identified. Thus, the median in the pre-test of the control group was 5 and in the post-test was 6,50; while in the experimental group the results are different. In the pre-test the median is 5 and in the post-test, the median is 11 .

Afterwards, the mode was calculated which is the number that most frequently appears in the general table of results. The mode in the pre-test of the control group was 4 and in the post-test was 6 . On the other hand, the mode of the experimental group in the pre-test was 5; while in the post- 
test was 11 .

In order to verify the effectiveness of Task-based learning approach on students' speaking skill, two hypotheses were established.

Alternative Hypothesis: Task-based learning approach improves students' speaking skill Null Hypothesis: Task-based learning approach does not improve students'speaking skill

First, it is needed to apply the Normality test with the error level of the Alpha 0,05 with a level of confidence of $95 \%$.

Table 3. Normal distribution test

\begin{tabular}{lcccc}
\hline \multicolumn{5}{c}{ Kolmogorov-Smirnov $^{\mathrm{a}}$} \\
\hline & $\begin{array}{c}\text { Statis- } \\
\text { tics }\end{array}$ & $\mathrm{gl}$ & Sig. & Stistics \\
\cline { 2 - 5 } Control group Pre test & 0,278 & 30 & 0 & 0,832 \\
Control group Post-test & 0,16 & 30 & 0,048 & 0,937 \\
$\begin{array}{l}\text { Experimental group pre-test } \\
\text { Experimental group post- } \\
\text { test }\end{array}$ & 0,248 & 30 & 0 & 0,915 \\
& 0,275 & 30 & 0 & 0,854 \\
\hline
\end{tabular}

Author: Soria, B. (2018)

Based upon the data displayed above, the level of significance of the control group in the pre-test is 0.832 and in the post-test is 0.937 ; additionally, the level of significance of the experimental group in the pre-test is 0.915 and in the post-test is 0.854 which are $>0.05$; therefore the data come from a normal distribution, or have a normal behavior, for both the control group and the experimental one in their two tests, pre and post-tests. From now, the process of data analysis can be continued.

\section{Statistics of paired samples}

Table 4. Statistics of paired samples

\begin{tabular}{|c|c|c|c|c|c|}
\hline \multicolumn{6}{|c|}{ Statistics of paired samples } \\
\hline & & Mean & $\mathrm{N}$ & $\begin{array}{l}\text { Standard } \\
\text { deviation }\end{array}$ & $\begin{array}{l}\text { Standard } \\
\text { error } \\
\text { mean }\end{array}$ \\
\hline Pair & Control group Pre test & 4,93 & 30 & 1,202 & 0,219 \\
\hline 1 & Control group Post-test & 6,6 & 30 & 1,453 & 0,265 \\
\hline & Experimental group pre-test & 5,3 & 30 & 1,466 & 0,268 \\
\hline 2 & $\begin{array}{l}\text { Experimental group post- } \\
\text { test }\end{array}$ & 10,83 & 30 & 1,577 & 0,288 \\
\hline
\end{tabular}

Author: Soria, B. (2018) 


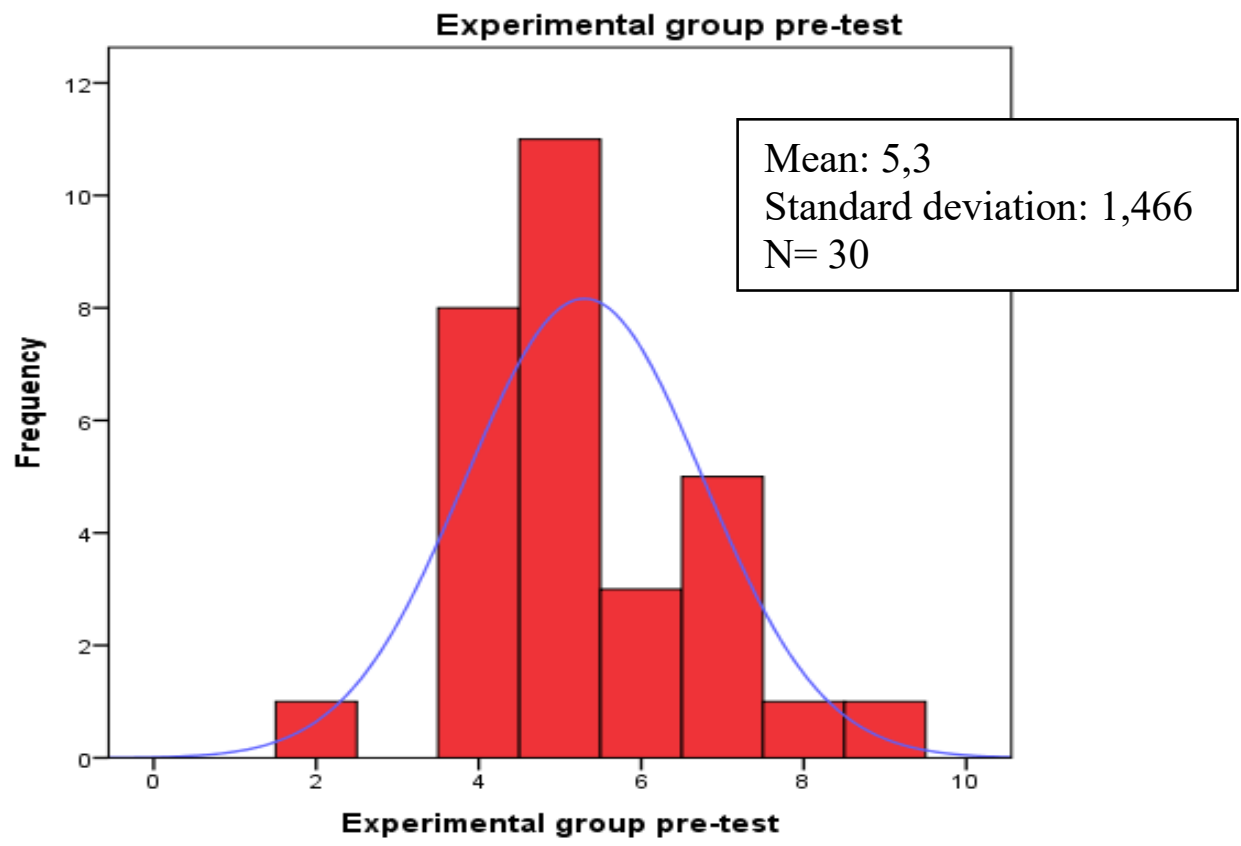

Figure 1. Histogram: Experimental group: Pre-test

Author: Soria, B. (2018)

Source: Table 4

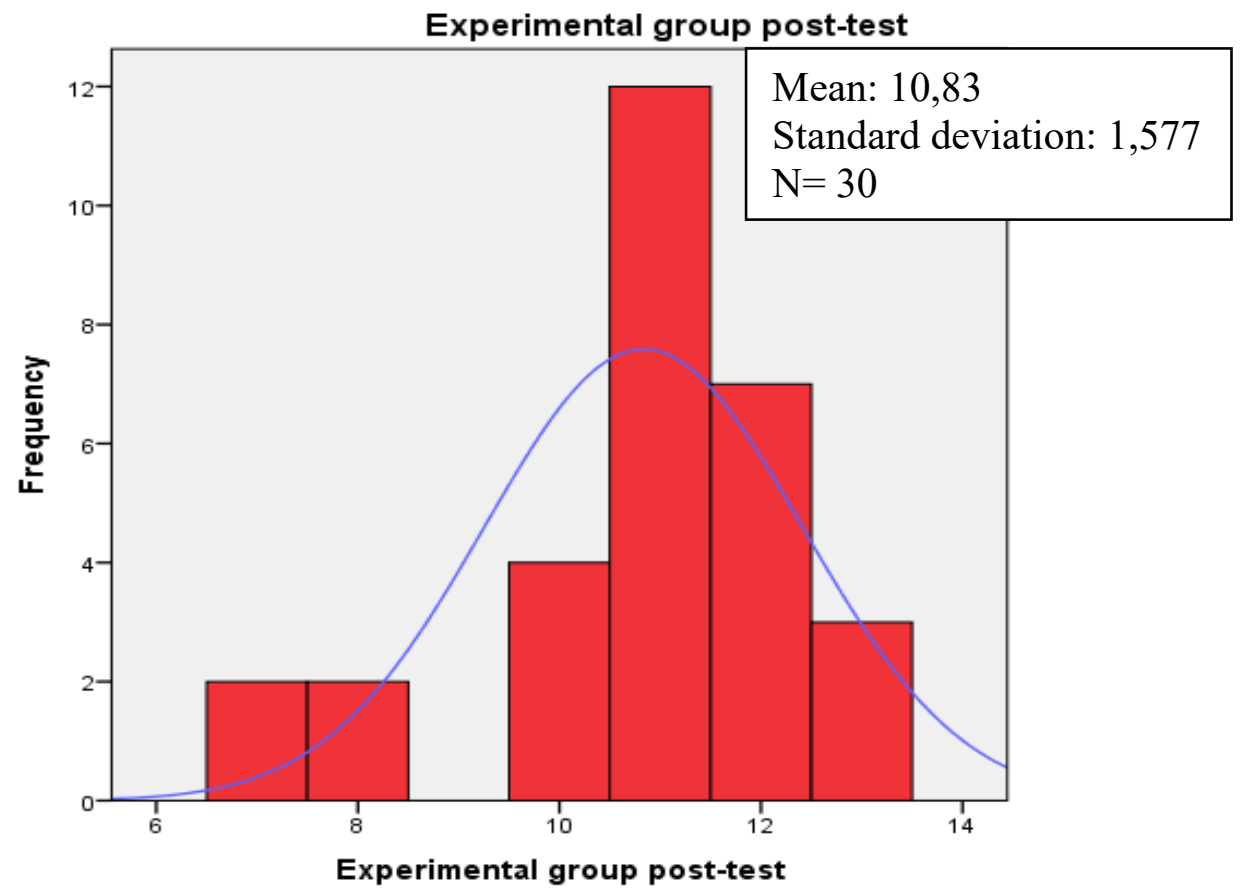

Figure 2. Histogram: Experimental group: Post-test

Author: Soria, B. (2018)

Source: Table 4 


\section{Analysis and interpretation}

Based upon the date displayed above, it is stated there is a slight difference between the means in the control group. It happens because the researcher did not develop the treatment with the control group. On the contrast, the means of the experimental group have a big difference between the means of the pre-test and the mean of the post-test. Indeed, this phenomenon happens because the researcher applied the Task-based approach learning in order to enhance speaking skill.

Table 5. Significance level

\begin{tabular}{|c|c|c|c|c|c|c|c|c|c|}
\hline \multicolumn{10}{|c|}{ Paired samples test } \\
\hline & & \multicolumn{5}{|c|}{ Paired differences } & \multirow{3}{*}{$\mathrm{t}$} & \multirow{3}{*}{$\mathrm{gl}$} & \multirow{3}{*}{$\begin{array}{l}\text { Sig. (bi- } \\
\text { lateral) }\end{array}$} \\
\hline & & \multirow[t]{2}{*}{ Mean } & \multirow{2}{*}{$\begin{array}{l}\text { Stand- } \\
\text { ard de- } \\
\text { viation }\end{array}$} & \multirow{2}{*}{$\begin{array}{l}\text { Standard } \\
\text { error } \\
\text { mean }\end{array}$} & \multicolumn{2}{|c|}{$\begin{array}{l}95 \% \text { difference } \\
\text { interval of con- } \\
\text { fidence } \\
\end{array}$} & & & \\
\hline & & & & & $\begin{array}{c}\text { Infe- } \\
\text { rior }\end{array}$ & $\begin{array}{c}\text { Supe- } \\
\text { rior }\end{array}$ & & & \\
\hline $\begin{array}{l}\text { Pair } \\
1\end{array}$ & $\begin{array}{l}\text { Control group Pre test } \\
\text { - Control group Post- } \\
\text { test }\end{array}$ & $-1,67$ & 1,422 & 0,26 & $-2,198$ & $-1,136$ & $-6,418$ & 29 & 0 \\
\hline $\begin{array}{l}\text { Pair } \\
2\end{array}$ & $\begin{array}{l}\text { Experimental group } \\
\text { pre-test - Experi- } \\
\text { mental group post-test }\end{array}$ & $-5,53$ & 1,383 & 0,252 & $-6,05$ & $-5,017$ & $-21,91$ & 29 & 0 \\
\hline
\end{tabular}

\section{Analysis and interpretation}

Hence there is a significance value of 0,000 which is $<0,05$ (the Alpha value), it is concluded that the alternative hypothesis is accepted and the null hypothesis is rejected. It means that the treatment which was developed by the researcher with students had a good impact. Therefore, the Task-based learning approach had a big significance for improving students' speaking skill. In fact, students belonging to the experimental group increased their average from 5,30 in the pretest to 10,83 in the post-test.

\section{Conclusions}

- First, the impact of the Task-Based learning approach has been determined in terms of enhancement of English speaking skills in the Language Center at Universidad Nacional de Chimborazo. The results from the before and after the teacher's treatment showed that it was a positive impact on students. The speaking skill was improved through the application of the proposal. 
- The initial state of students' oral production was established based on the diagnostic test when the semester started, which was very helpful for the establishment of the problem of research; and, with the pre-test results before the researcher's intervention.

- The components of the process of Task-based approach to enhance English speaking skills were analyzed through the implementation. In this process, pre-task activities, task activities, and post-task activities were applied in the proposal in order to help students to achieve their learning goals.

- Useful tasks such as pair/group, open/close, information gap, opinion gap tasks; for example, role-play, debates, questioning, and simulations were explored, which were very helpful to enhance learners' speaking skills through the use of Task-based approach. All of the tasks were developed in a motivational and engaging way in order to promote students' oral interaction.

- The effectiveness of the task-based approach for the development of the speaking skill in the English language was assessed. Thus, the treatment was carried out in order to obtain data for analysis and interpretation. The data assessment was performed along-side its implementation of the proposal, which demonstrated that the proposal was ef-fective for the improvement of learners' speaking skills.

\section{Referencias Bibliográficas}

Bernal, C. (2010). Metodología de la Investigación. Pearson. Bogotá.

British Council. (2015). English in Ecuador. Retrieved from https:/ei.britishcouncil.org/sites/default/files/latin-americaresearch/English\%20in\%20Ecuador.pdf

Crystal, D. (2003). English as a Global Language. New York: Cambridge University Press.

Crystal, D. (2008). Dictionary of Linguistics and Phonetics. Malden: Blackwell Publishing.

Ellis, R. (2003) Task-based language learning and teaching. Oxford: OUP.

Gonzales, P., Ochoa, C., Castillo, L., Cabrera, P., Quiñonez, A., Solano, L., .. U Ulehlova, E. (2015). EFL Teaching in the Amazon Region of Ecuador: A Focus on Activities and Resources for Teaching Listening and Speaking Skills . Retrieved from https://files.eric.ed.gov/fulltext/EJ1075454.pdf

Leong, L.-M., \& Ahmadi, S. (2016). An Analysis of Factors Influencing Learners' English Speaking Skill. Retrieved from International Journal of Research in English Education: http://ijreeonline.com/article-1-38-en.pdf

Miles, M. B., \&Huberman, A. M. (1984). Qualitative data analysis. Beverly Hills.

Peña, M. \&Onatra, A. (2009) Promoting Oral Production through the Task-Based Learning Approach: A Study in a Public Secondary School in ColombiaVol. 11, No. 2, 2009. ISSN 
1657-0790. Bogotá, Colombia. Pages 11-26.

Quezada, P., Benítez, C., Vargas, A., \& Zúñiga, A. (2017). Factors that Influence the English Language Teaching-Learning Process in Ecuadorian High Schools in the context of Eeducation and E-Society. Retrieved from https://www.researchgate.net/publication/309511514_Factors_that_Influence_the_English _Language_Teaching-

Learning_Process_in_Ecuadorian_High_Schools_in_the_context_of_E_education_and_E-Society

Samuda, V. 2001 "Guiding relationships between form and meaning during task performance”. In Bygate, M. Skehan, P. and Swain, M. (eds). 2001. 119-140.

Vromen, A. (2010). Debating Methods: Rediscovering Qualitative Approaches. In Marsh, P. \& Stoker, G. (Eds.), Theory and Methods in Political Science (p. 249 - 266). China: Palgrave MacMillan.

Williams, G. (2018). Using audiobooks to meet the needs of adolescent readers. American Secondary Education, 105-114.

Zacharias, N. T. (2012). Qualitative research methods for second language education: A course book. Cambridge Scholars Publishing.

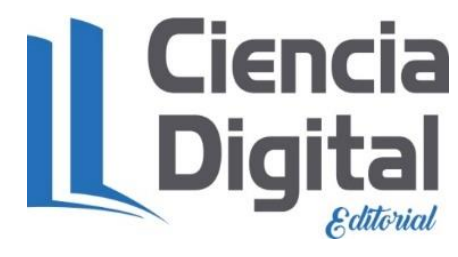




\section{PARA CITAR EL ARTÍCULO INDEXADO.}

Bravo Montenegro, M. A., Soria Guerrero, B. R., \& Ureña Lara, D. A. (2020). Enfoque de aprendizaje basado en tareas en el desarrollo de la habilidad del habla. ConcienciaDigital, 3(1.1), 181-193. https://doi.org/10.33262/concienciadigital.v3i1.1.1139

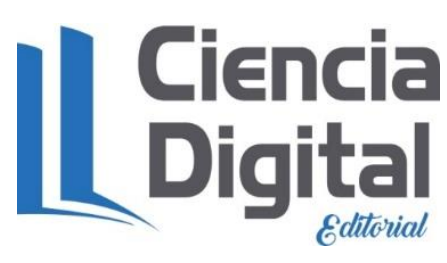

El artículo que se publica es de exclusiva responsabilidad de los autores y no necesariamente reflejan el pensamiento de la Revista Conciencia Digital.

El artículo queda en propiedad de la revista y, por tanto, su publicación parcial y/o total en otro medio tiene que ser autorizado por el director de la Revista Conciencia Digital.

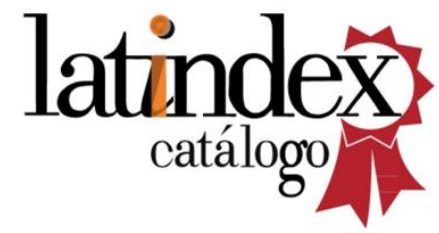

